\title{
EFEKTIVITAS PENDEKATAN VALUE CLARIFICATION TECHNIQUE BERBASIS KARAKTER KEMANDIRIAN PADA KETERAMPILANN PEMECAHAN MASALAH
}

\author{
Sumliyah, M.Pd \\ Pendidikan Matematika \\ Universitas Muhammadiyah Cirebon \\ Jl. Watubelah Kabupaten Cirebon \\ exsasumliyah@gmail.com
}

\begin{abstract}
Abstrak
Gerak langkah pendidikan tidak akan terpisahkan dari arus perkembangan sains dan teknologi, tuntutan kuantitas dan kualitas produk pendidikan, teori pendidikan dan kenyataan di lapangan. Nilai-nilai moral sebagai landasan yang harus ada dan tertanamkan dalam pembelajaran matematika. Penulisan makalahinibertujuan mengimplementasikan pembelajaran dengan pendekatan Value Clarification Tehnique (VCT) berbasis karakter kemandirian pada keterampilan pemecahan masalah, materi program linear kelas X SMK Kartika Kota Cirebon semester 2 Tahun Pelajaran 2015/ 2016 berjumlah 23 siswa yang efektif dengan metode penelitian eksperimen.Teknik pengambilan sampel dengan cara purposive sample di mana penelitian ini mengambil sampel 5 orang dari satu kelas yang dijadikan penelitian dengan pertimbangan kemampuan yang beragam, yaitu sangat tinggi, tinggi, sedang dan kurang baik. Siswa pada kelas tersebut memperoleh pembelajaran dengan pendekatan value clarification technique berbasis karakter. Data Keterampilan Pemecahan Masalah (KPM) diolah dengan uji t, uji pengaruh dengan uji regresi dan uji peningkatan diolah dengan uji gain Hasil penelitian ini sebagai berikut:Pembelajaran matematika dinyatakan efektif, yaitu: 1) KPM mencapai ketuntasan individual dengan nilai rataan 83,00, KPM mencapai ketuntasan klasikal dengan ketuntasan mencapai $85 \%$; 2) adanya pengaruh positif karakter kemandirian sebesar 0,883; dan 3) Adanya peningkatan proses pembentukan keterampilan pemecahan masalah.
\end{abstract}

Kata Kunci : Pendekatan Value Clarification Technique (VCT), Keterampilan Pemecahan Masalah, karakter kemandirian.

\section{PENDAHULUAN}

Matematika adalah salah satu ilmu yang dapat meningkatkan pemahaman konsep, penalaran, komunikasi, dan pemecahan masalah (Jihad dan Haris, 2009: 148). Kenyataan di lapangan menunjukkanbahwa aspek-aspek tersebut belum terrealisasikan bahkan prestasi belajar siswa masih rendah. Banyak orang yang menganggap bahwa matematika sebagai mata pelajaran yang sulit untuk dikuasai, sehingga matematika merupakan matapelajaran yang kurang disenangi. Pandangan ini secara psikologi berpengaruh pada kondisi pribadi peserta didik sebelum materi matematika diberikan sehingga penguasaan konsep tidak dapat maksimal. Dengan adanya penerapan konsep matematikayangdiajarkan oleh guru matematika dengan berbasis pendidikan karakter diharapkan pesera didik dapat memahami apa yang disampaikan dan dibarengi dengan penanaman karakterkarakter yang dapat dibentuk oleh peserta didik. Menurut Zubaedi (2012:17) Pendidikan karakter merupakanupaya penenaman kecerdasan dalam berpikir, pengahayatan dalam bentuk sikap, dan pengamalan dalam bentuk perilaku yang sesuai dengan nilainilai luhur yang menjadi jati dirinya, diwujudkan dalam interaksi dengan Tuhannya, diri sendiri, antarsesama dan lingkungannya

Pemaparan yang berkaitan dengan kesulitan yang dialami siswa dirasakan oleh peneliti ketika peneliti mengajar matematika di SMK Kartika di mana mata pelajaran matematika kurang dipahami dengan baik khususnya pada Keterampilan pemecahan masalah. Matematika masih merupakan mata 
pelajaran yang dianggap sulit, kurang diminati, dan dihindari oleh sebagian besar siswa. Peneliti melakukan kajian lebih dalam lagi untuk mengetahui materi matematika yang paling sulit untuk dipahami siswa. Diperoleh data dari hasil ulangan harian pada soal-soal yang berkaitan dengan pemecahan masalah atau soal cerita diperoleh hasil yang kurang baik atau kurang dari KKM.

Berdasarkan pengamatan peneliti, salah satu materi matematika kelas $\mathrm{X}$ yang dipandang sukar oleh kebanyakan siswa SMK Kartika Cirebon dalam memecahkan masalah adalah materi program linear. Materi program linear terutama sub pokok bahasan menentukan model matematika dari soal cerita merupakan materi yang cukup membutuhkan kemampuan dan keterampilan pemecahan masalah yang tinggi untuk memahamaminya sehingga pada umumnya guru mengalami kesulitan dalam penyampaiannya. Menurut Preisseien (Ahmadi dkk, 2011: 110) bahwa keterampilan pemecahan masalah adalah keterampilan individu dalam menggunakan proses berpikir untuk memecahkan masalah melalui pengumpulan fakta-fakta, analisis informasi, menyusun berbagai alternatif pemecahan, dan memilih pemecahan masalah yang paling efektif.

Keterampilan pemecahan masalah yang dibangun selama proses pembelajaran adalah keterampilan yang harus dimiliki siswa dalam melakukan tahapan pemecahan masalah Polya (Suherman dkk, 2001: 84) yaitu (1) memahami masalah; (2) merencanakan penyelesaian; (3) menyelesaikan masalah sesuai rencana; (4) dan melakukan pengecekan kembali dari setiap langkah penyelesaian. Sedangkan pembentukan perilaku siswa yang menjadi indikator kemandirian belajar selama proses pembelajaran yaitu (1) Initiative (prakarsa); (2) Creativity (daya cipta); (3) Innovation (pembaharuan/ penemuan baru); (4) Improvisation (pengembangan/ penyempurnaan); dan (5) Pro-active (aktif) (Sumahamjaya, 2003: 19).

Salah satu upaya guru maupun peneliti untuk mencari solusi dengan mengembangkan pembelajaran menggunakan perangkat pembelajaran yang didesain dengan menerapkan pendekatan Value Clarification Technique(VCT) berbasis karakter untuk meningkatkan keterampilan pemecahan masalah. Menurut Simon (Adisusilo, 2012: 155) bahwa dengan pendekatan teknik klarifikasi nilai kita dapat meningkatkan peserta didi untuk: (1) memilih, memutuskan, nilai dan perasaanya; (2) berempati (memahami perasaan orang lain, melihat dari sudut pandang orang lain); (3) memecahkan masalah; (4) menyatakan sikap: setuju, tidak setuju, menolak atau menerima pendapat orang lain; (5) mengambil keputusan; dan (6) mempunyai pendirian tertentu, menginternalisasikan dan bertingkah laku sesuai dengan nilai yang telah dipilih dan diyakini.

Penelitian ini bertujuan agar mengetahuikeefektifan pembelajaran matematika dengan pendekatan VCT untuk meningkatkan keterampilan pemecahan masalah. Sebagaimana hasil yang ditunjukan NCTM (Wilson, 1993.66) dijelaskan bahwa terdapat lima alasan yang mendasar kenapa pembelajaran matematika harus menggunakan pemecahan masalah, alasannya yaitu (1) pemecahan masalah merupakan bagian yang paling penting dalam matematika; (2) matematika mempunyai pemecahan masalah banyak aplikasi dan sering menggambarkan masalah penting dalam kehidupan nyata; (3) terdapat motivasi hakiki tertanam dalam pemecahan masalah matematika; (4) pemecahan masalah dapat menjadi sesuatu yang menyenangkan; (5) pemecahan masalah harus ada dalam kurikulum sekolah, agar mampu mengembangkan Keterampilan pemecahan masalah.

Dalam hal ini peneliti akan menerapkan pembelajaran dengan pendekatan Value Clarification Technique(VCT) berbasis karakter untuk meningkatkan Keterampilan pemecahan masalah yang mampu memfasilitasi terbentuknya karakter kemandirian belajar dan keterampilan pemecahan masalah selama proses pembelajaran yang efektif di SMK Kartika Kota Cirebon.

\section{KAJIAN PUSTAKA}

\section{Pendidikan Karakter}

Karakter berasal dari bahasa Yunani yang berarti "to mark" menandai dan memfokuskan pada bagaimana menerapkan nilai-nilai kebaikan dalam tindakan nyata atau perilaku sehari-hari (Mulyasa, 2012: 3). Menurut Alwisol Karakter juga dapat diartikan sebagai gambaran tingkah laku yang menonjolkan nilai benar-salah, baik-buruk, baik secara eksplisit maupun implisit (Zubaedi, 2012: 11). Dari pengertian atau definisi-definisi di atas 
dapat disimpulkan bahwa karakter merupakan tingkah laku yang ditandai dengan nilai kebaikan atau sebaliknya yang diterapkan/ dilakukan dalam kehidupan sehari-hari.

Pendidikan karakter mempunyai misi untuk mengembangkan watak-watak dasar yang seharusnya dimiliki oleh peserta didik, yang menjadikan ciri bahwa peserta didik telah mendapatkan ilmu atau pengetahuan yang disampaikan oleh guru maupun komponen pendidikan lainnya. Nilai-nilai moral atau karakter yang harus ditanamkan oleh siswa dan diajarkan oleh sekolah yaitu diantaranya kejujuran, keadilan, toleransi, kebijaksanaan, kemandirian, kerjasama, dan toleransi.

Sementara itu menurut pakar pendidikanSuyanto (Zubaedi, 2012: 8081)terdapat sembilan pilar karakter yang berasal dari nilai-nilai luhur universal manusia. Sembilan pilar karakter itu antara lain: 1) cinta Tuhan dan segenap ciptaan-Nya; 2) kemandirian dan tanggung jawab; 3) kejujuran/ amanah; 4) hormat dan santun; 5) dermawan, suka menolong, dan gotong royong/ kerja sama; 6) percaya diri dan pekerja keras; 7) kepemimpinan dan keadilan; 8) baik dan rendah hati; dan 9) toleransi, kedamaian, dan kesatuan.

Dengan melihat sembilan pilar dan identifikasi nilai yang dikembangkan dalam pendidikan karakter di indonesia dapat disimpulkan bahwa nilai karakter menjadi dasar pada proses pendidikan karena dari lembaga pendidikan, generasi penerus dicetak dan dilahirkan.

\section{Karakter Kemandirian}

Karakter yang diambil dan akan ditanamkan dalam pemelitian ini yaitu karakter kemandirian. Kajian dalam nilai karakter merupakan kajian pada ranah afektif, yang berfokus pada karakterisasi yaitu karakter mandiri siswa dalam pembelajaran matematika dengan pendekatan VCT materi program linear. Kata mandiri mengandung arti tidak tergantung pada orang lain dan dapat melakukan sendiri (Rusman, 2010: 353)

Menurut Elfindri, dkk (2012: 101-102) karakter mandiri merupakan sikap dan prilaku yang tidak mudah tergantung kepada orang lain dalam menyelesaikan tugas-tugas tertentu. Selain itu karakter mandiri juga merupakan kemampuan untuk berdiri sendiri, melakukan tugas dan tanggung jawab yang dilakukannya. karakter kemandirian masalah pada dasarnya diartikan sebagai orang yang tidak mau bekerja sama dalam tim atau kelompoknya.Ditegaskan oleh Elfindridkk (2012: 276) bahwa karakter anak yang diharapkan adalah kualitas mental atau kekuatan moral, akhlak atau budi pekerti yang merupakan kepribadian khusus yang harus melekat kepada anak-anak bangsa.

Mengacu pada indikator yang dikemukakan oleh Sumahamijaya, dkk (2003: 19), sehingga indikator karakter mandiri pada penelitian ini adalah sebagai berikut:

A. Initiative (prakarsa)

1. Selalu menggunakan ide dan gagasannya

2. Berantusias dalam menyambut tugas yang diberikan guru

3. Berusaha dengan maksimal dalam menyelesaikan problem solving moral.

4. Memfokuskan perhatian dalam kegiatan belajar mengajar.

B. Creativity (daya cipta)

1. Mampu memulai strategi pemecahan soal yang diberikan guru

2. Menciptakan strategi pemecahan soal yang lebih cepat dibandingkan teman lainnya.

3. Mempunyai rasa ingin tahu yang tinggi

4. Mengerjakan tugas sesuai dengan kemampuannya sendiri

C. Innovation (pembaharuan/ penemuan baru)

1. Aktif dalam menciptakan hal yang baru dalam menyelesaikan masalah.

2. Memberikan pendapat untuk menyelesaikan permasalahan dengan mengemukakan ide yang baru.

3. Berani menunjukkan bahwa hasil pengerjaan tugas merupakan pemikiran sendiri

D. Improvisation (pengembangan/ penyempurnaan)

1. Dapat mengembangkan ide lain yang lainnya

2. Berlatih secara kontinu dalam menghadapi masalah

3. Berjuang untuk menyelesaikan permasalahaan dengan tuntas

\section{E. Pro-active}

1. Berani menyampaikan pendapat yang berbeda dari orang lain.

2. Aktif berkomunikasi dengan teman untuk menyelesaikan masalah 
3. Berusaha mencari informasi bila dihadapkan dengan permaslahan

4. Berusaha menampilkan diri bahwa dia dapat menyelesaikan masalah

5. Selalu mencari alternatif dalam menyelesaikan persoalan atau maslah.

\section{Pemecahan Masalah}

Menurut Polya (Suherman dkk, 2001: 84), solusi dalam memecahkan soal pemecahan masalah memuat empat langkah penyelesaian yang akan dijelaskan atau diuraikan indikator serta kegiatan dari setiap langkah pada Tabel 2.1 berikut:

1. Memahami masalah

2. Merencanakan Penyelesaian

3. Menyelesaikan masalah sesuai rencana

4. Melakukan pengecekan kembali

Pemecahan masalah berarti keikutsertaan dalam suatu tugas atau aktivitas yang strategi atau metode pemecahannya tidak diketahui sebelumnya. Memecahkan masalah bukan saja merupakan suatu sasaran belajar matematika tetapi sekaligus merupakan alat utama untuk melakukan belajar itu. Sebagaimana dijelaskan oleh Wahyudin (2008: 27) bahwa pemecahan masalah adalah bagian integral dari belajar matematika. Dengan demikian pemecahan masalah jangan dijadikan bagian yang terpisah dari program matematika karena menajdi bagian yang tidak terpisahkan dalam menyelesaikan permasalahanpermasalahan yang ada dalam pembelajaran matematika.

\section{Keterampilan Pemecahan Masalah}

Keterampilan pada peneilitian ini mengacu pada langkah atau fase-fase yang digunakan Polya (Suherman dkk, 2001: 84) dalam pemecahan masalah dan dijadikan sebagai indikator dalam penelitian ini, sehingga indikator keterampilan yang dijadikan pedoman untuk melihat keterampilan atau action siswa dalam proses pemecahan masalah yaitu:

A. Keterampilan memahami masalah

1. Terampil menuliskan apa yang diketahui sesuai dengan permasalahan awal

2. Terampil menerapkan pengalaman hidupnya untuk menyelesaikan tugas

3. Terampil dalam melakukan eksplorasi untuk menjawab semua tugas
4. Terampil menuliskan apa yang ditanyakan sesuai dengan permasalahan awal

5. Terampil memunculkan ide atau gagasan alternatif dalam pemecahan masalah

6. Terampil mengkomunikasikan halhal yang diketahui dalam persoalan yg dihadapi

7. Terampil menyusun kalimat verbal ke dalam model matematika

B. Keterampilan membuat rencana penyelesaian

1. Terampil mengidentifikasi strategistrategi pemecahan masalah yang sesuai, untuk menyelesaikan msalah dengan baik

2. Terampil membuat rumusan yang berhubungan dengan permasalahan yang disajikan

C. Keterampialan menyelesaikan masalah sesuai rencana

1. Terampil menunjukkan langkahlangkah menyelesaikan persoalan

2. Terampil menngkomunikasikan penyelesaiannya dengan teman yang lain

3. Terampil menyelesaikan masalah dengan kritis dan logis

D. Keterampilan pengecekan kembali semua langkah yang telah dikerjakan

1. Terampil menunjukkan jawaban final dari persoalan yng dihadapi

2. Terampil menafsirkan penyelesaian yang telah diperoleh

3. Terampil menuliskan rangkuman dari persoalan yang diberikan padanya

4. Terampil dalam menyajikan jawaban

5. Terampil mengidentifikasi adakah cara lain untuk mendapatkan penyelesaian masalah.

6. Terampil dalam membuat suatu kesimpulan dalam pemecahan masalah

7. Terampil dalam menyimak penguatan yang diberikan guru

Dari uraian diatas maka disimpulkan bahwa keberhasilan belajar tidak hanya dilihat dari kemampuan siswa menyelesaikan tes yang diberikan pada akhir suatu pembelajaran, tetapi perlu memperhatikan kemampuan siswa mengikuti tahap-tahap pembelajaran yang mengarah pada kemandirian siswa dalam menyelesaikan permasalahan atau keterampilan siswa. Jadi keterampilan yang ditunjukkan oleh siswa selama proses 
pembelajaran

dipertimbangkan

berlangsung,

perlu keberhasilan belajar siswa.

\section{Pembelajaran dengan Pendekatan VCT}

Proses penentuan nilai dan sikap dengan penerapan pendekatan pembelajaran VCT mencakup tujuh subproses atau aspek yang biasanya digolongkan menjadi tiga kategori. Ada tiga proses klarifikasi nilai menggunakan pendekatan VCT menurut Hall dan Simon (Adisusilo, 2012: 147) menjelaskan dalam tiga proses tersebut terdapat tujuh sub proses. Setiap tahapan dijelaskan seperti Tabel 2.2.

Kemampuan memahami hubungan antar konsep sehingga membutuhkan kekritisan siswa, kematangan dalam bernalar dan keterlibatan secara aktif dalam pembelajaran merupakan bagian yang diperlukan dalam memecahkan masalah. Dengan demikian pembelajaran menggunakan pendekatan teknik klarifikasi penilaian (VCT) dapat diharapkan menjadi salah satu alternatif pembelajaran yang dapat membantu siswa dalam meningkatkan kemampuan meyelesaikan pemecahan masalah matematika

\section{METODOLOGI}

Tabel 1

Proses Klarifikasi Nilai Pada Pendekatan Pembelajaran VCT

\section{PROSES SUBPROSES}

\begin{tabular}{ll}
\hline 1. Memili 1) & Memilih secara bebas \\
h & Artinya kesempatan untuk \\
& menentukan pilihan yang \\
& menurutnya baik. Nilai yang \\
& dipaksakan tidak akan menjadi \\
& miliknya secara penuh. \\
2) & Memilih dari berbagai alternatif \\
& Artinya, untuk menentukan \\
& pilihan dari beberapa alternatif \\
& pilihan secara bebas. \\
3) & Memilih dari berbagai alternatif \\
& setelah mengadakan pertimbangan \\
& tentang berbagai akibatnya
\end{tabular}

2. Meng hargai /

menju njung tinggi

3. Bertin dak a) Menghargai dan merasa bahagia dengan pilihannya Artinya adanya perasaan senang dan bangga dengan nilai yang menjadi pilihannya, sehingga nilai tersebut akan menjadi bagian integral dari dirinya

b) Bersedia mengakui/ menegaskan pilihannya itu di depan umum. Artinya, bila kita menganggap nilai itu suatu pilihan, maka kita akan berani dengan penuh kesadaran untuk menunjukkannya didepan orang lain

1) Berbuat/ berprilaku sesuatu sesuai dengan pilihannya

2) Berulang-ulang bertindak sesuai dengan pilihannya hingga akhirnya merupakan pola hidupnya dalam kehidupan sehari-hari. a. Populasi dan Sampel

Populasi merupakan keseluruhan objek yang dijadikan sebagai penelitian sedangkan sampel adalah sebagian objek dari populasi. Pada penelitian ini, yang menjadi populasi adalah SMK Kartika Kota Cirebon dan yang menjadi sampel penelitian adalah kelas XI Keperawatan, di mana dari satu kelas tersebut diambil 6 siswa dengan komposisi 2 siswa dengan tingkat kemampuan atas, 2 siswa dengan tingkat kemampuan sedang dan 2 siswa dengan tingkat kemampuan yang rendah.

b. Desain Penelitian

Penelitian ini merupakan penelitian eksperimen yaitu penerapan pembelajaran matematika yang efektif denganpendekatanVCT untuk meningkatkan Keterampilan pemecahan masalah siswa materi program linear.Teknik pengambilan sampel dengan cara purposive sample yaitu pengambilan sampel didasarkan atas adanya tujuan tertentu (Arikunto, 2006: 141). Merujuk dari teknik pengambilan teknik sampel tersebut sehingga peneliti mengambil sampel 5 orang dari satu kelas yang dijadikan penelitian dengan pertimbangan kemampuan yang beragam, yaitu sangat tinggi, tinggi, sedang dan kurang baik. Siswa pada kelas tersebut memperoleh pembelajaran dengan Pendekatan pembelajaran VCT berbasis karakter matematis.Instrumen penelitian yang digunakan untuk mengumpulkan data pada penelitian ini terdiri ataslembar observasi karakter dan keterampilan pemecahan masalah, wawancara, dan instrumen tes Keterampilan pemecahan masalah. Metode pengumpulan data yang digunakan dalam penelitian ini adalah metode tes, observasi, dan wawancara. 
c. Alur Pengolahan Data

Analisis uji keefektifan yang pertama yaitu melakukan uji prasyarat dengan menguji normalitas data yang bertujuan untuk mengetahui apakah data sampel berdistribusi normal atau tidak. Penerimaan Ho dengan menggunakan signifikansi yang diperoleh dari kolom Kolmogorof-Smirnov program SPSS yaitu jika nilai sig $>5 \%$. Analisis data akhir dalam penelitian ini berupa nilai tes Keterampilan pemecahan masalah sebagai hasil belajar yaitu uji ketuntasan dalam mencapai KKM dengan menggunakan uji satu pihak. Rumus yang digunakan dalam menganalisis uji ketuntasan yaitu dengan uji $\mathrm{t}$ dengan membandingkan tabel dengan $\mathrm{dk}=\mathrm{n}-1$ dengan kriteria pengujian 5\%. $\mathrm{H}_{0}$ ditolak jika $t_{\text {hitung }} \geq t_{(1-\alpha)}$ (Sudjana, 2005: 231).

Uji ketuntasan klasikal digunakan uji proporsi satu pihak. Rumus yang digunakan uji z. Selanjutnya hasil tersebut dibandingkan dengan nilai ztabel dengan criteria pengujian $5 \% . \mathrm{H}_{0}$ diterima jika Zhitung $>\mathrm{z}(0,5-\alpha)$.

Analisis uji regresi ganda dalam penelitian ini menggunakan program SPSS. $\mathrm{H}_{0}$ ditolak jika nilai sig lebih kecil dari $5 \%$. Selanjutnya untuk mengetahui besarnya kontribusi variabel $\mathrm{X}_{1}$ dan $\mathrm{X}_{2}$ terhadap $\hat{Y}$ dapat dilihat dari nilai $R$ square (Sukestiyarno, 2012).Untuk mengetahui peningkatankemandirian belajar siswa dan keterampilan pemecahan masalahsiswa pada kelas uji coba perangkat berdasarkan pengamatan dapat dilihat berdasarkan grafik peningkatan selama kegiatan uji coba

\section{HASIL DAN PEMBAHASAN}

\section{a. Deskripsi Hasil Tes}

Kegiatan dalam penelitian ini yaitu pembelajarandikatakan efektif jika, (1) pembelajaran dengan menggunakan pendekatan VCT tuntas KKM; (2) ada pengaruh positif antara karakter kemandirian dan keterampilan pemecahan masalah; (3) terdapat peningkatan karakter kemandirian dan keterampilan pemecahan masalah. Adapun hasil yang diperoleh pada penelitian ini adalah sebagai berikut:

\section{1) Uji ketuntasan pencapaian KKM}

Nilai Keterampilan pemecahan masalah kelas uji coba perangkat menggunakan uji rata-rata satu pihak. Dengan rumus yang telah disebutkan di atas maka diperoleh: nilai rata-rata kelas $(\bar{x})=83,00$; nilai ratarata yang dihipotesiskan/KKM $\left(\mu_{o}\right)=7,00$; simpangan baku sampel $(\mathrm{s})=8,46$; banyaknya sampel $(n)=28$ dengan menggunakan taraf signifikan $5 \%$ dan $\mathrm{dk}=$ $(28-1)=27$ diperoleh nilai $\mathrm{t}_{\text {tabel }}=2,05$. Diperolehthitung $>\mathrm{t}_{\text {tabel }}$ maka thitung $=$ $8,46>2,05$ sehingga $\mathrm{H}_{0}$ ditolak, artinya ratarata Keterampilan pemecahan masalah kelas uji coba perangkat lebih besar dari 70 Jadi Keterampilan pemecahan masalah tuntasKKM.Uji pencapaian ketuntasan klasikal digunakan uji proporsi satu pihak dilakukan untuk mengetahui apakah banyaknya siswa yang mencapai ketuntasan telah mencapai sekurangkurangnya 85\%. Dengan menggunakan uji proporsi yang telah disebutkan di atas maka diperoleh hasil perhitungannya yaitutolak Ho jika $\mathrm{Z}_{\text {hitung }} \geq \mathrm{Z}_{\text {tabel. }}$ Pada kelas eksperimen didapatkan Zhitungyaitu 1,69 dan Ztabel yaitu 1,64dengan tingkat kesalahan 5\% maka $\mathrm{H}_{0}$ ditolak, sehingga bisa disimpulkan bahwa proporsi siswa pada kelas yang diberi perlakuan mencapai KKM 70 telah melampaui 85\%.

\section{2) Uji pengaruh}

Variabel bebas dalam penelitian ini adalah karakter kemandirian $(X)$, sedangkan variabel terikat adalah Keterampilan pemecahan masalah $(\hat{Y})$. Data tentang karakter kemandirian dan keterampilan pemecahan masalah diambil dari hasil pengamatan pada saat tes Keterampilan pemecahan masalah (TKPM) yang dilaksanakan pada akhir pertemuan. Berdasarkan hasil yang diperoleh nilai $R$ Square $=0,883=88,3 \%$. Hal ini berarti 88,3\% Keterampilan pemecahan masalah siswa dipengaruhi oleh karakter kemandirian dan keterampilan pemecahan masalah dalam menyelesaikan soal-soal latihan (secara bersama-sama), sedangkan $11,7 \%$ dipengaruhi oleh faktor lain. Sedangkan persamaan regresinya adalah $\hat{Y}=-11,208+0,517 X$ artinya setiap penambahan variabel karakter kemandirian $(X)$ sebesar satu satuan maka akan menambah nilai Tes Keterampilan pemecahan masalah $(Y)$ sebesar 0,517.Berikut dijelaskan pada Tabel 1 . hasil rekapitulasi dari karakter kemandirian dari semua pertemuan pada 6 siswa pilihan, sebagai berikut

b. Analisis Data 
Tabel 2 Rekapitulasi Nilai

Karakter kemandirian

\begin{tabular}{|c|c|c|c|c|c|c|}
\hline \multirow{2}{*}{ No } & \multirow{2}{*}{ Subyek } & \multicolumn{5}{|c|}{ Pertemuan } \\
\hline & & I & II & III & IV & V \\
\hline \multirow[t]{2}{*}{1} & S-01 & 4,2 & 4,4 & 4,7 & 4,6 & 4,9 \\
\hline & & 0 & 4 & 1 & 0 & 1 \\
\hline \multirow[t]{2}{*}{2} & S-02 & 3,7 & 3,8 & 4,1 & 4,4 & 4,7 \\
\hline & & 1 & 1 & 8 & 5 & 5 \\
\hline \multirow[t]{2}{*}{3} & S-03 & 3,2 & 4,1 & 4,0 & 4,1 & 4,4 \\
\hline & & 3 & 8 & 5 & 7 & 9 \\
\hline \multirow[t]{2}{*}{4} & S-04 & 3,7 & 3,8 & 3,9 & 4,0 & 4,2 \\
\hline & & 1 & 7 & 9 & 5 & 0 \\
\hline \multirow[t]{2}{*}{5} & S-05 & 2,8 & 3,7 & 3,8 & 3,9 & 4,4 \\
\hline & & 6 & 8 & 7 & 7 & 5 \\
\hline \multirow[t]{3}{*}{6} & S-06 & 2,7 & 3,5 & 4,0 & 4,0 & 4,5 \\
\hline & & 5 & 4 & 3 & 3 & 8 \\
\hline & & 3,4 & 3,9 & 4,1 & 4,2 & 4,5 \\
\hline & a-rata & 1 & 4 & 4 & 1 & 6 \\
\hline \multicolumn{2}{|c|}{ Rata-rata } & \multicolumn{5}{|c|}{ 4,05 (Mulai } \\
\hline \multicolumn{2}{|c|}{ Keseluruhan } & \multicolumn{5}{|c|}{ Berkembang) } \\
\hline
\end{tabular}

Dari tabel rekapitulasi tersebut di atas, diperoleh rata-rata 4,05 artinya dengan penerapan pendekatan VCT karakter kemandirian siswa mulai berkembang sehingga peneliti dapat membandingkan dengan menggunakan pendekatan Value Clarification Technique (VCT) akan lebih sesuai digunakan pada subjek penelitian dalam kelompok tertentu,hal ini diperkuat dengan adanya bukti dari nilai uji gain dari keenam subjek penelitian. Berikut Tabel 1. yang menyajikan data uji gain karakter kemandirian dari subjek pilihan penelitian.

Tabel 3 Uji Gain Karakter

Kemandirian pada Subjek Pilihan

Penelitian

\begin{tabular}{|c|c|c|c|c|c|c|}
\hline \multirow[b]{2}{*}{ Subjek } & \multicolumn{6}{|c|}{ Pertemuan } \\
\hline & $\begin{array}{l}\text { I } \\
\& \\
\text { II }\end{array}$ & $\begin{array}{c}\text { II } \\
\& \text { I } \\
\text { II }\end{array}$ & $\begin{array}{l}\text { III } \\
\& I \\
\text { V }\end{array}$ & $\begin{array}{c}\text { IV } \\
\& \\
\text { V }\end{array}$ & $\begin{array}{l}\text { V } \\
\& \\
\text { I }\end{array}$ & $\begin{array}{l}\text { Ra } \\
\text { ta- } \\
\text { ra } \\
\text { ta }\end{array}$ \\
\hline & 0 & 0,4 & 0,5 & 0,7 & 0 & 0,6 \\
\hline S-01 & 54 & 9 & 0 & 3 & 72 & 0 \\
\hline & 0 & 0,3 & 0,4 & 0,4 & 0 & 0,4 \\
\hline S-02 & 51 & 6 & 0 & 2 & 52 & 4 \\
\hline & 0 & 0,3 & 0,3 & 0,5 & 0 & 0,4 \\
\hline S-03 & 41 & 2 & 8 & 3 & 54 & 4 \\
\hline & 0 & 0,3 & 0,3 & 0,5 & 0 & 0,4 \\
\hline S-04 & 40 & 0 & 2 & 1 & 54 & 1 \\
\hline & 0 & 0,5 & 0,4 & 0,4 & 0 & 0,4 \\
\hline S-05 & 43 & 6 & 4 & 6 & 34 & 5 \\
\hline & 0 & 0,3 & 0,4 & 0,5 & 0 & 0,4 \\
\hline S-06 & 35 & 3 & 2 & 7 & 56 & 5 \\
\hline $\begin{array}{c}\text { Rata-rata } \\
\text { Keseluruha } \\
\mathbf{n} \\
\end{array}$ & \multicolumn{6}{|c|}{ 0,46 (Sedang) } \\
\hline
\end{tabular}

Setelah diuraikan setiap subjek pada setiap kelompok berikut disajikan hasil rekapitulasi dari karakter kemandirian dari semua pertemuan pada 6 siswa pilihan, dijelaskan pada Tabel 4.

Tabel 4. Rekapitulasi Nilai Karakter kemandirian

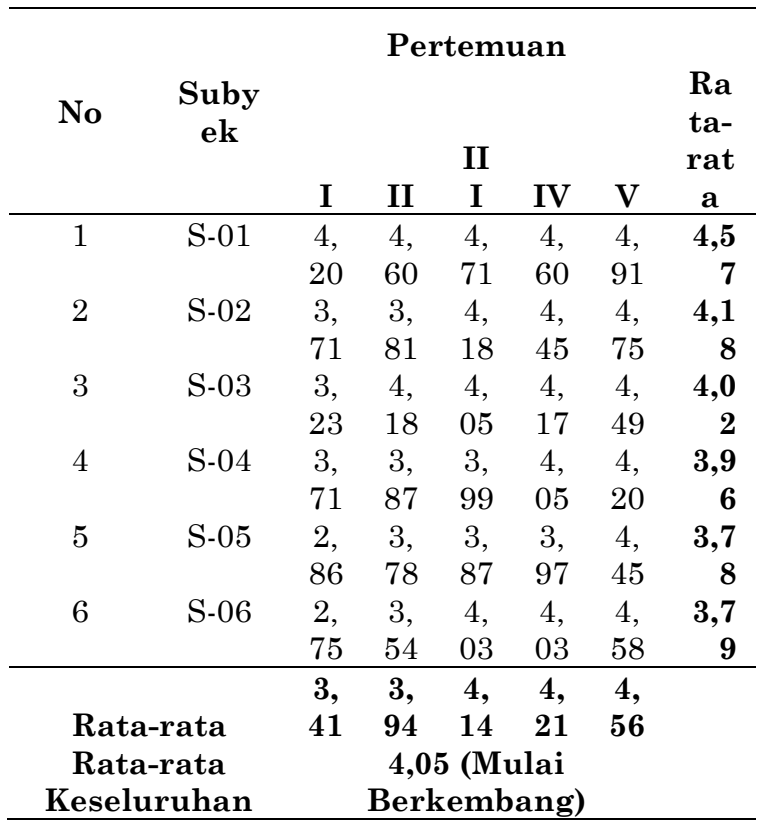

Dari tabel rekapitulasi di atas, diperoleh rata-rata 4,05 artinya dengan penerapan pendekatan VCT karakter kemandirian siswa mulai berkembang sehingga peneliti dapat membandingkan bahwa pengembangan perangkat dengan menggunakan pendekatan Value Clarification Technique (VCT) berbasis karakter akan lebih sesuai digunakan pada subjek penelitian dalam kelompok tertentu,hal ini diperkuat dengan adanya bukti dari nilai uji gain dari keenam subjek penelitian. Berikut tabel 4.20 yang menyajikan data uji gain karakter Pada Subjek Pilihan Penelitian Dari grafik 1 dapat disimpulkan bahwa pembelajaran dengan pendekatan Value Clarification Technique (VCT) akan lebih sesuai digunakan pada subjek penelitian kelompok bawah baik yang pertama maupun kedua karena berdasarkan pengamatan skor rata-rata dan uji gain kelompok bawah pada akhir pembelajaran dia melebihi skor rata-rata kelompok atas yang kedua

Peningkatan pada variabel pengamatan keterampilan juga akan ditunjukan pada Tabel 5. mengenai hasil rekapitulasi dari keterampilan pemecahan masalah dari semua 
pertemuan pada 6 siswa pilihan, sebagai berikut:

Tabel 5. Rekapitulasi Nilai Keterampilan pemecahan masalah

\begin{tabular}{|c|c|c|c|c|c|c|c|}
\hline \multirow[t]{2}{*}{ No } & \multirow[t]{2}{*}{$\begin{array}{l}\text { Sub } \\
\text { yek }\end{array}$} & \multicolumn{5}{|c|}{ Pertemuan } & \multirow[t]{2}{*}{$\begin{array}{l}\text { Jum } \\
\text { lah }\end{array}$} \\
\hline & & I & II & I & IV & V & \\
\hline \multirow{3}{*}{1} & \multirow{3}{*}{ S-01 } & 3 & 4 & 4 , & 4, & 4 & 21,5 \\
\hline & & 90 & 00 & 45 & 45 & 75 & 5 \\
\hline & & 3 & 3 & 4 & 4, & 4, & 20,4 \\
\hline \multirow[t]{2}{*}{2} & \multirow{2}{*}{ S-02 } & 25 & 85 & 30 & 45 & 55 & 0 \\
\hline & & 2 & 3 & 3 & 3, & 4, & 17,5 \\
\hline \multirow[t]{2}{*}{3} & \multirow[t]{2}{*}{ S-03 } & 65 & 25 & 40 & 80 & 40 & 0 \\
\hline & & 2 & 3 & 3 & 3 & 4 & 17,8 \\
\hline \multirow[t]{2}{*}{4} & \multirow[t]{2}{*}{ S-04 } & 40 & 20 & 95 & 95 & 30 & 0 \\
\hline & & 2 & 3 & 3 , & 3 & 4 & 17,6 \\
\hline \multirow[t]{2}{*}{5} & \multirow[t]{2}{*}{ S-05 } & 20 & 40 & 80 & 95 & 30 & 5 \\
\hline & & 2 & 3 & 3 & 4, & 4 & 17,1 \\
\hline 6 & S-06 & 25 & 40 & 35 & 00 & 15 & 5 \\
\hline \multirow{3}{*}{\multicolumn{2}{|c|}{$\begin{array}{c}\text { Rata-rata } \\
\text { Rata-rata } \\
\text { Keseluruhan }\end{array}$}} & 2 & 3 & 3 & 4 , & 4 , & \\
\hline & & 78 & 52 & 88 & 10 & 41 & \\
\hline & & \multicolumn{5}{|c|}{ 3,74 (Baik/ Terampil) } & \\
\hline
\end{tabular}

Dari tabel rekapitulasi di atas,

diperoleh rata-rata 3,73 artinya dengan penerapan pendekatan VCT keterampilan pemecahan masalah siswa selama 5 pertemuan dikategorikan terampil sehingga peneliti dapat membandingkan bahwa pengembangan perangkat dengan menggunakan pendekatan Value Clarification Technique (VCT) berbasis karakter akan lebih sesuai digunakan pada subjek penelitian dalam kelompok tertentu,hal ini diperkuat dengan adanya bukti dari nilai uji gain dari keenam subjek penelitian. Berikut Tabel 6 . yang menyajikan data uji gain keterampilan pemecahan masalah dari subjek pilihan penelitian.

Tabel 6.

Uji Gain Keterampilan Pemecahan Masalah pada Subjek Pilihan Penelitian

\begin{tabular}{ccccccc}
\hline & \multicolumn{7}{c}{ Pertemuan } \\
\cline { 2 - 7 } Subjek & I & II & III & IV & V & $\begin{array}{c}\text { Ra } \\
\text { ta- }\end{array}$ \\
& $\mathbf{\&}$ & $\mathbf{\& I}$ & $\mathbf{\& I}$ & $\mathbf{\&}$ & $\mathbf{8}$ & ra \\
& II & II & V & V & I & ta \\
\hline & 0, & 0,6 & 0,6 & 0,7 & 0, & $\mathbf{0 , 6}$ \\
S-01 & 54 & 5 & 9 & 8 & 79 & $\mathbf{9}$ \\
& 0, & 0,5 & 0,6 & 0,6 & 0, & $\mathbf{0 , 6}$ \\
S-02 & 53 & 3 & 0 & 3 & 71 & $\mathbf{0}$ \\
& 0, & 0,5 & 0,5 & 0,6 & 0, & $\mathbf{0 , 5}$ \\
S-03 & 43 & 1 & 8 & 1 & 68 & $\mathbf{6}$ \\
& 0, & 0,5 & 0,5 & 0,5 & 0, & $\mathbf{0 , 4}$ \\
S-04 & 30 & 0 & 1 & 2 & 55 & $\mathbf{8}$ \\
& 0, & 0,5 & 0,5 & 0,6 & 0, & $\mathbf{0 , 5}$ \\
S-05 & 20 & 6 & 5 & 6 & 71 & $\mathbf{4}$
\end{tabular}

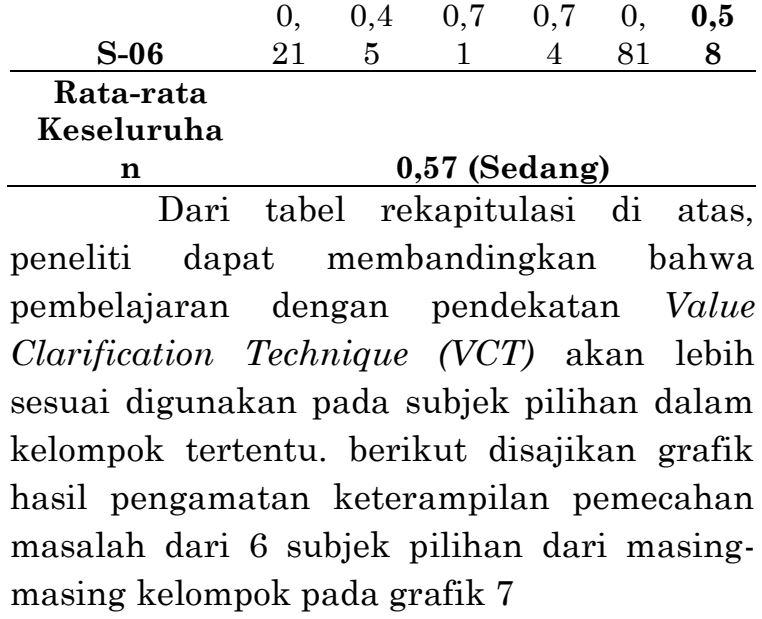

\section{KESIMPULAN DAN SARAN}

a. Kesimpulan

Implementasi pembelajaran matematika dengan pendekatan VCT berbasis karakter pada materi program linearkelas $\mathrm{X}$ yang dikembangkan dengan metode penelitian eksperimen. Hasil analisis terhadap keefektifan pembelajaran tersebut efektif, yaitu Keterampilan pemecahan masalah matematis kelas yang diberi perlakuan mencapai ketuntasan dengan melampaui 70 sebagai KKM, terdapat pengaruh positif karakter kemandirian dan keterampilan pemecahan masalah terhadap Keterampilan pemecahan masalahsiswa sebesar $88,3 \%$, serta terjadi peningkatan karakter kemandiriansiswa dan keterampilan pemecahan masalah pada keenam siswa pilihan di kelas yang menggunakan pembelajaran dengan pendekatan VCT berbasis karakter dan kesesuian pembelajaran dengan menggunakan pembelajaran dengan pendekatan VCT berbasis karakter pada subjek penelitian kelompok bawah

b. Saran

Berdasarkan hasil pembelajaran dengan pendekatan VCT berbasis karakter pada materi program linearkelas $\mathrm{X}$, peneliti dapat memberikan saran yaitu pembelajaran dalam penelitian ini dapat digunakan guru sebagai alternatif dalam proses pembelajaran karena pembelajaran dapat dilaksanakan denganefektif. Sedangkan bagi peneliti yang akan mengadakan penelitian lanjutan, penelitian ini masih banyak kekurangandiantaranya:pengaruh

karakter kemandirian dan keterampilan pemecahan masalah terhadap Keterampilan pemecahan masalah hanya 
sampai $88,3 \%$ yang artinya $11,7 \%$ dipengaruhi faktor lain artinya dapat dilakukan penelitian yang lanjut untuk meminimalisir faktor lain yang berpengaruh sehingga penerapan pendekatan VCT yang lebih dominan berpengaruh; peningkatan pembentukan pada karakter kemandirian dan keterampilan pemecahan masalah diperoleh pada kriteria sedang artinya dengan dilaksanakannya penelitian yang lebih lanjut, tidak menutup kemungkinan akan lebih meningkat dan memperoleh peningkatan dengan kriteria tinggi

\section{DAFTAR PUSTAKA}

Adisusilo, S. 2012. Pembelajaran Nilai Karakter (konstruktivisme dan VCT sebagai Inovasi Pendekatan Pembelajaran Afektif).Jakarta: PT Raja Grafindo Persada.

Ahmadi, I.K., Setyono, H.A., dan Amri, S. 2011. Pembelajaran Akselerasi (Analisis Teori dan Praktik serta Pengaruhnya terhadap Mekanisme Pembelajaran dalam Kelas Akselerasi. Jakarta: Prestasi Pustaka PublisherKumar Singh, Y. (2006). Fundamental of Research Methodology and Statistics. New Delhi: New Age International (P) Ltd.

Plomp, Tjeerd. 2007. "An Introduction to Educational Design Research". Proceedings of the Seminar Conducted at the East China Normal University, Shanghai (PR China), November 23-26.

Sudjana. 2005A. Metode Statistika. Bandung: Tarsito.

Sugiyono. 2007. Metode Penelitian Pendidikan Pendeketan Kuantitatif, Kualitatif, dan $R \& D)$. Bandung: Alfabeta.

Suherman, dkk. 2001. Common Textbook Strategi Pembelajaran Matematika Kontemporer. Bandung: Jurusan Pendidikan Matematika UPI Bandung.

Sukestiyarno. 2012. Olah Data Penelitian Berbantuan SPSS. Semarang : Universitas Negeri Semarang.
Sumahamijaya, S. dkk. 2003. Pendidikan Karakter Mandiri dan Kewiraswastaan (Suatu Upaya bagi Keberhasilan Program Pendidikan Berbasis Luas/ Broad Based Education dan Life Skills. Bandung: Angkasa Bandung.

Trianto. 2007. Model Pembelajaran Terpadu dalam Teori dan Praktek. Jakarta: Prestasi Putaka Publisher.

Wilson, P.1993. Research Ideas for The Classroom High School Mathematics (Mathematical Symbols and Representations). Macmillan Publishing Company. 